\title{
РЕЦЕНЗИИ
}

DOI: $10.22363 / 2313-2272-2018-18-4-787-791$

\section{HOW HISTORICAL SHOULD HISTORICAL SOCIOLOGY BE?* Review of the book: Šubrt J. The Perspective of Historical Sociology: The Individual as Homo-Sociologicus Through Society and History. Bingley: Emerald Group Publishing; 2017. 312 pp.}

What role does an individual play in history? In his book J. Šubrt considers some answers to this question in the perspective of historical sociology, i.e. based on the theory of modernization, dilemma of individualism-holism, and the general influence of history on our understanding of society. The author defines historical sociology as a branch of sociology, thus, focusing only on the terms and issues relevant to historical sociology. This book provides the reader with an overview of the key thinkers' idea on historical sociology beginning from the founders of sociology such as Karl Marx, Max Weber, Herbert Spencer, Emile Durkheim, and Auguste Comte, and then explaining the contribution of modern thinkers to the field of historical sociology - Norbert Elias, Anthony Giddens, Jaroslav Krejči, Schmul Eisenstadt, Immanuel Wallerstein, Niklas Luhmann, Zygmunt Bauman, and many others. Such a big list of contributors is determined by the author's definition of historical sociology as an interdisciplinary science aiming at solving complex problems of the contemporary society including the eternal dichotomy of individualism and holism as overcome by the theory of social roles.

The book consists of seven parts including an introduction to historical sociology. The main part of the book - chapters $2-6$ - consider different questions of historical sociology, and the final part presents the author's interpretation of the individual's role in society. In the introduction, the author gives a brief definition of historical sociology and a short overview of its history. Historical sociology is not a just a combination of history and sociology but rather a part of sociology focusing on history to explain society and the development of its social structures. The author identifies key periods in the development of sociology as waves: the first wave came in the nineteenth century and continued until the 1920s - it was a period of 'great theories' with a 'natural' historical component. The second wave came in the 1920s and continued

* C H. Behrends, 2018.

The article was submitted on 07.08.2018. 
until the 1950s - sociology forgot about theory and history and focused on empirical research and applied studies. Theory returned to sociology in the 1950s for scientists recognized the necessity to analyze the 'big data', and the most prominent representative of this wave is Talcott Parsons. In the 1970s, historical sociology was recognized an accepted as a way to make historical differences an integral part of explaining and understanding social phenomena (pp. 4-6). In particular, Šubrt emphasizes the importance of Charles Mills's works for understanding the individual's role in social history: previously individuals and the past were a historians' domain but today historical sociology aims at explaining their role in social development (p. 7).

In the main part of the book - chapters $2-6$ - the author considers key issues of historical sociology such as the role of time in history and 'temporalized sociology', social changes, domain of macro-sociology, 'civilizing process', challenges of modernization, and other questions related to these main categories of historical sociology. Šbrt provides a detailed description of the role of time in history based on the works of Patrick Baert, who introduced the term 'temporalized sociology', and Norbert Elias. Temporalized sociology focuses on three questions: how different cultures understand time, how time is rationalized and used in a systematic way in society (i.e. calendars and different structures of time depending on occupation), and what role time plays in sociology. The role of time in sociological theory and the idea that some sociological theories are not universal are relatively new concepts for sociology (pp. 25-27).

Thus, the author considers the theory of Fernand Braudel and how he interprets both time and the role of the individual in history and society. Braudel believes that there are two ways to define time: the short-term 'court durée' and the long-term 'longue durée'. Braudel was first to recognize the importance of long timespans: he argues that individual actors and 'great personalities' cannot influence history because the 'longue durée', i.e. long-term history, cannot be influenced by single events or people but only by slow rhythmic unfolding of time through the development of such macro-factors as economy affecting individuals and individual events (pp. 29-31). Therefore, the author refers to the works of Niklas Luhmann, Teinhart Koselleck, and Karl Popper who recognized the role of the past and history in predicting the future: history, the present time and future are not exactly the same, so history's validity in predicting the future is questionable; according to Luhmann, today society is developing much faster than in the past, so the future is not predictable (p. 32).

Our understanding of time and progress has changed. Pre-modern societies had no concept of past or future because they lived in the same time continuum. The notions of future and progress appeared in the Middle Ages and dominated until the problems of modernization became apparent and denied the version of history as following a linear progressive path (p. 35). Šubrt considers the modern interpretation of time through the rigid time schedules on the monastery — such 'rationalization' of time determined modernization (p. 99). Society often tries to follow an artificial ideal dependent on the political and cultural climate of the time. For instance, utopian ideas with no plans of social development and its structures inspired many social reforms. 
Monastery way of life is an example of such a utopian ideal. In the utopian society, we can often find political and/or social situation of the time that inspired the utopia, so the ideal often reflects the historical reality and cannot be universal for any time and space. However, later the emphasis was made on the secular way of life and we forgot about the influence of the monastery way of life on modern life (pp. 101-102).

The rejection of the idea of social progress lead to the idea of 'social change' as an explanation of social development, i.e. the questions of how and why societies change in the way they do. Social changes vary in speed and significance, and the typical approach to social changes is to identify who/what influences changes (p. 33). Šubrt considers three basic types of social changes in sociology - cyclical, discontinuous, and linear - and theories of crisis, collapse and revolution as key approaches to the study of social change (p. 35). He argues that we need new theories of social change and that interdisciplinary approaches such as historical sociology can explain crisis, collapse and acceleration of change (pp. 52-53). For instance, the author considers the theory of crisis on the example of Immanuel Wallerstein who believes that the world today is in a current state of crisis and its eventual is plausible (p. 65).

In the fourth part of the book, macro-sociology is presents as a theory of social structures, systems and functions developed by Emile Durkheim, Auguste Comte and Herbert Spencer who defined society in a holistic way as a social organism; later this idea changed to the analogy of a system (p. 119). Šubrt explains forces that contribute to the functioning of social system and notes a dualism in the form of consensus versus conflict (p. 128). Sociological thought originally emphasized cohesive measures that bound society together such as the division of labor, and Talcott Parson's theory of functionalism was dominant until the end of the Second World War. Then Lewis Coser and Ralf Dahrendorf explained that conflict is a normal state of society and examined the role of conflict in binding societies together (p. 130). Subrt presents different ways the conflict theory is used today emphasizing that we are not so much interested in conflicts as in a 'stand-still' situation. However, the conflict theory is popular in the study of international relations (realism), in political philosophy, political science, economic dependency theory, postcolonial studies, ethnic and terrorism studies, sociology of war and revolutions within historical sociology, theories of state building, etc. (p. 136).

'Civilizing process' is another important concept of the book, and the author considers Norbert Elias's explanation of how society became civilized by people trying to emulate aristocratic courts. Šubrt identifies two aspects of the civilizing process: psychogenesis, i.e. the formation of "personality, manners, and development of behavior", and sociogenesis, i.e. the formation of inequality, power, and order in the state and society. These aspects are interdependent for psychogenesis needs a stable society to develop and sociogenesis needs people that can control their behavior. Thus, Elias analyzes dining etiquette and how human emotions and instincts were refined and repressed (for instance, shame and embarrassment were used to shape personality and self-control). According to Elias, the state is based on taxation and armed forces that were created by monarchs to control large areas, which lead to a peaceful society. 
Another example of such repressed behavior is sport, in which wild emotions can be expressed in a civilized way (pp. 161-167). Therefore, civilizing process is an effect of modern civilization that determined the development of the modern nation-state.

Part 4 focuses on modernization and its effects as a crucial aspect of historical sociology for problems of modernization made sociologists reconsider the issues of time and progress (p. 197). Modernization is studied in historical sociology through its key components such as industrialization, nation-state and capitalism. Thus, there are different theories to how capitalism developed: Karl Marx believed that capitalism is the result of capital accumulation and related processes such as marketization; Max Weber defined capitalism as the result of changes in the mentality of people due to Protestantism and its interpretation of rationality; Norbert Elias focused on civilizing process as a combination of the modern state with changes in mentality (pp. 183-184). Further in this chapter Šubrt analyzes negative effects of modernization, the role of conflicts and violence in it, and different types of modern societies. Modernization required reinterpretation of society and questioned the idea of linear progressive path of history. Šubrt mentions Zygmunt Bauman's interpretation of the Holocaust as an effect of modernization and the modern nation-state (p. 197), and considers as similar effects environmental problems (industrial state pollutes air, water, and soil) (p. 221) and negative changes in personal relationships that decrease the level of social trust (p. 223).

The final section of the book emphasizes the individual's role in society. In general, history notices individuals but sociology does not due to the dominant holism (p. 255). Obviously, individual actors can influence history, and although holism is still dominant in sociology, historical sociologists seek to discover social mechanisms and structures that allow individual actors to influence social development (p. 256). Šubrt considers the history of individualism versus holism dichotomy: thus, Durkheim believed in holism, supra-individual actors that influence individual actions, and that society transcends the individual (pp. 234-235). Modern society became more individualistic, and the duality of individualism and holism lead to the theories of exchange and rational choice as based on individualism, and structuralism, functionalism and systems theory as based on holism (p. 235). Historical sociology seeks a way to combine holism and individualism to explain society. Subrt believes that one possible way to bridge the gap between holism and individualism is a theory of social roles that has been ignored since the 1970s (p. 243). On the one hand, social roles are expectations of the social circle; on the other hand, individuals have a certain degree of freedom within their social roles' limitations. But how do individual actors influence macro-events? Sociology does not answer this question for it focuses on macro-events in the functionalist perspective, i.e. the holistic approach is still dominant even in historical sociology although there are leaders of social change that cannot be ignored and should be considered as macro-actors (pp. 254-256).

The Perspective of Historical Sociology convincingly shows that for every theory there is an opposite theory, that is why there are no truths in sociology but rather a set of possible interpretations each with a reliable explanation of some social fragment 
in the given time and place. This idea that there are no grand universal explanations is a key component of historical sociology that differentiates it from classical sociological theories; however, the author recognizes and emphasizes the importance of the founders of traditional sociology influence on historical sociology. It is a relatively new field of study, and most of its issues are open to (re)interpretation, which is why the reader finishes the book with a feeling that there is still no adequate solution to 'bridge the gap' between the individual and society in sociology although the author proved that historical sociology can be a solution.

\begin{abstract}
НАСКОЛЬКО ИСТОРИЧНОЙ ДОЛЖНА БЫТЬ ИСТОРИЧЕСКАЯ СОЦИОЛОГИЯ?*

Рецензия на книгу: Šubrt J. The Perspective of Historical Sociology: The Individual as Homo-Sociologicus Through Society and History. Bingley: Emerald Group Publishing; 2017.312 c.
\end{abstract}

* (C) Берендс Х., 2018.

Статья поступила в редакиию 07.08.2018. 